\title{
Prevalence of Hepatitis B Virus (HBV) and Hepatitis C Virus (HCV) In Hepatocellular Carcinoma Patients Attending A Cancer Hospital
}

\author{
Dr.B.Sridevi Chaitanya ${ }^{1}$, Dr.D.Radha Rani ${ }^{2}$ \\ ${ }^{I}$ (Department of Microbiology, Basavatarakam Indo American Cancer Hospital \& Research Institute, \\ Hyderabad, India) \\ ${ }_{2}^{2}$ (Department of Microbiology, Basavatarakam Indo American Cancer Hospital \& Research Institute, \\ Hyderabad, India)
}

\begin{abstract}
:
Purpose: The most common etiological agents for hepatocellular carcinoma $(H C C)$ are hepatitis $B$ virus $(H B V)$ and hepatitis $C$ virus $(H C V)$. The present study was aimed to assess the seroprevalence of hepatitis $B$ surface antigen (HBsAg) and antibodies to HCV among patients with HCC, attending a cancer hospital. Method: A retrospective study of patients with histologically and radiologically proven HCC between July 2014 and April 2016 were evaluated for HBsAg and anti-HCV antibodies by Enhanced Chemiluminescence Immuno Assay (CLIA) method using the VITROS ECI/ECiQ Immunodiagnostic systems.

Result: Out of 116 HCC patients, 34 (29.31\%) were having HBsAg positivity and HCV positivity was seen in 15(12.93\%). Co-infection by $\mathrm{HCV}$ and $\mathrm{HBV}$ was found in 3 (2.58\%) patients. Males are affected more than females and most of them are in their fifth or sixth decade. Alpha feto protein levels were higher in $85(73.27 \%)$ of patients and serum aminotransferase levels are higher than the reference range.

Conclusion: The high seropositivity of $H B V$ and $H C V$ in HCC suggests their role as the causative agents of Hepatocellular carcinoma.
\end{abstract}

Keywords: Anti-HCV antibodies, hepatocellular carcinoma, hepatitis B surface antigen, hepatitis B virus, hepatitis $C$ virus.

\section{Introduction}

Hepatocellular carcinoma (HCC) is the most frequent cause of all liver cancers and constitutes $90 \%$ of cancers of liver globally. The mortality in HCC is very high; about 7 Lakh deaths occur annually due to HCC and have been estimated to be $3^{\text {rd }}$ common cause of death due to cancers effecting human [1]. In India the age adjusted incidence rate of $\mathrm{HCC}$ for men ranges from 0.7 to 7.5 and for women 0.2 to 2.2 per 100,000 populations per year [2]. Hepatitis B virus (HBV) is the most common etiologic factor for HCC in Asian countries. It accounts for up to three-fourth cases of HCC, while hepatitis C virus (HCV) infection may account for $10-15 \%$. Globally, an estimated 248 million people are chronically infected with hepatitis B, and approximately 110 million people have chronic hepatitis C infection (WHO - Guidelines on Hepatitis B and Hepatitis C testing, February 2017). In India nearly 45 million people are suffering from chronic HBV infection with a point prevalence of $3.7 \%$ and approximately 15 million people are with chronic $\mathrm{HCV}$ infection with a population prevalence of 1\% [3]. Although many factors including dietary aflatoxin B1 (AFB1) and alcoholic and non-alcoholic fatty liver diseases can lead to HCC, globally most HCC cases are due to HBV and HCV. The $\mathrm{HBsAg}$ positivity in Indian HCC patients varies from $36 \%$ to $74 \%$. Serological evidence of HCV infection in patients with HCC in India is 15\% [4].

Hepatitis B and C viruses are members of two different viral families, but both display a strong hepatotropism. HBV is thought to be carcinogenic in an indirect fashion, such as by insertional activation of cellular oncogenes, the induction of genetic instability upon HBV DNA integration or by the regulatory protein $\mathrm{HBx}$ as well as by modulation of host immune reponses. HCV is likely to predispose to cancer by alteration of cell signalling and metabolism as well as by modulating and inducing immune responses [5]. The aim of this study is to know the prevalence of Hepatitis B surface antigen (HBsAg) and anti HCV antibodies among HCC patients

\section{Materials And Methods}

This was a retrospective study in which records of all patients diagnosed as HCC from July 2014 to April 2016 admitted in Basavatarakam Indo-American Cancer Hospital and Research Institute, Hyderabad were reviewed. Demographic data including age and sex were collected. Serological, Biochemical, Radiological and Histological details were reviewed. 
All serum samples were tested for Hepatitis B surface antigen (HBsAg) and anti HCV antibodies by Enhanced Chemiluminescence Immuno Assay (CLIA) technique using VITROS ECi/ECiQ Immunodiagnostic Systems. The diagnosis of HCC was done on the basis of histological findings or cytology. For cases in which no histological evidence was available, patients were diagnosed radiologically in a setting of underlying risk factors, along with a clearly elevated serum alpha-fetoprotein $(>100 \mathrm{ng} / \mathrm{ml})$. Of all 116 patients, 91(78.44\%) were diagnosed based upon histology or cytology, while 25 (21.55\%) were diagnosed with imaging along with other features.

\section{Results}

A total of 119 patients diagnosed with HCC from July 2014 to April 2016 were reviewed. Three patients were excluded due to incomplete records. Total 116 patients were included for analysis. Out of 116 HCC patients, 34 (29.31\%) were having HBsAg positivity and HCV positivity was seen in 15(12.93\%). Coinfection $(\mathrm{HBV} / \mathrm{HCV})$ was seen in $3(2.58 \%)$ patients. (The chi-square statistic is 9.4069 . The $p$-value is 0.002162. This result is significant at $\mathrm{p}<0.05$ ) (Table 1). More no. of HBsAg and HCV positive cases were found in between age group of 31-70 among HCC and the association of age group having test positive in HCC was found to be significant statistically ( $p=0.03$ ) (Table 2). Among HBsAg positive cases males are more affected than females (The chi-square statistic is 5.334. The $p$-value is 0.020913 . This result is significant at $p<$ 0.05) (Table 3). Among HCV positive cases also males are affected more than females but the results are not significant statistically. (The chi-square statistic is 0.0049 . The p-value is 0.944012 . This result is not significant at $p<0.05$ ) (Table 4) Alpha fetoprotein level $>100 \mathrm{ng} / \mathrm{ml}$ was present in $85(73.27 \%$ ) of patients. Twenty nine $(85.29 \%)$ HBsAg positive patients $(\mathrm{n}=34)$ are having $>100 \mathrm{ng} / \mathrm{ml}$ AFP levels whereas among HCV positive patients $(\mathrm{n}=15) 11(73.33 \%)$ are having high AFP levels above $>100 \mathrm{ng} / \mathrm{ml}$. High AFP was observed in HBsAg positive and HCV positive cases but the association was found to be insignificant statistically $(\mathrm{p}>0.05)(\mathrm{Chi}-$ square $=2.053$ with 1 degree of freedom; $p=0.152$ ) (Table 5) All the patients had impaired liver function in one or more of serum aminotransferases. Out of 116 patients $67(57.75 \%)$ had aspartate aminotransferase (AST), 21 $(18.10 \%)$ alanine aminotrensferase (ALT) and $63(54.31 \%)$ alkaline phosphatise (ALP) levels above the reference range.

\section{Discussion}

The risk factors of $\mathrm{HCC}$ include hepatitis $\mathrm{B}$ virus infection, hepatitis $\mathrm{C}$ virus infection, aflatoxicosis, alcoholism, smoking, and hereditary conditions such as hemochromatosis, alpha-antitrypsin deficiency, tyrosinaemia, anabolic steroids and oestrogen levels [6]. HCC due to HBV and HCV may be an indirect result of enhanced hepatocyte turnover that occurs in an effort to replace infected cells that have been immunologically attacked. Viral functions may also play a more direct role in mediating oncogenesis [7]. In the present study the overall viral seropositivity was $45 \%$ showing that the probability of infections with hepatitis B and $\mathrm{C}$ as risk factors for HCC is high $(p=0.002)$. This finding suggests that most HCC cases were the result of a hepatotropic virus-related chronic liver disease. This result is in accordance to the estimation that HBV is responsible for $50 \%$ to $80 \%$ of HCC cases worldwide, whereas $10 \%$ to $25 \%$ of the cases are thought to be caused by HCV infection. (7). A recent study from Delhi shows that among the HCC patients, $68.9 \%$ were HBV related, $21.3 \%$ were $\mathrm{HCV}$ related. The presence of any marker positive for HBV increased the risk for developing HCC by almost 27 times [OR: 27.33; (12.87-60.0)]. An increased risk of 10.6 times was observed for HCC development for cases positive for any HCV marker [OR: 10.55; (3.13-42.73)] [8]. Another study from North West part of India also showed that hepatitis B was the common risk factor and was seen in $65.3 \%$ followed by hepatitis $\mathrm{C}$ in $11.6 \%$ of $\mathrm{HCC}$ cases [9]. A recent study from North West part of India shows that HBV association was found in $84.8 \%$ of the HCC cases, whereas HCV association was found in $15.2 \%$ of the HCC cases [10].

Although HBV and HCV may be independent risk factors of HCC, dual infection is likely to increase the risk of primary hepatocellular carcinogenesis. In our study co-infection by HCV and HBV was found in 3 (2.58\%) patients with HCC which is less than reported by Manash et al from Delhi (5.3\%) [8]. A study from Zimbabwe had reported that $8 \%$ of hepatocellular carcinoma cases are co-infected by HCV and HBV [11]. The incidence of HCC increases with age [4]. Studies from India have shown the maximum incidence of HCC in the fifth to sixth decade $[4,8,9]$. Present study also shows the maximum number of HCC cases in fifth and sixth decade only. The age range of hepatitis B induced HCC was 31-70 yrs whereas hepatitis C induced HCC was seen in the fifth and sixth decade only. The difference in the age of occurrence of HCC in hepatitis B induced and hepatitis $\mathrm{C}$ induced HCC may be due to the difference in the transmission of both the viruses, hepatitis $\mathrm{B}$ mostly transmitted vertically (mother-chid), hepatitis $\mathrm{C}$ is transmitted horizontally as a result of exposure to infectious body fluids. Compared to hepatitis C induced HCC, the young age associated with hepatitis B induced HCC due to vertical transmission urges the need to screen HCC at an early age, no later than early adulthood [12]. 
In the present study, male dominance was seen which is similar to other studies from India and other countries $[4,8,9,11,13]$. The male predominance in HCC may be explained by greater exposure of males to other environmental carcinogens, consumption of alcohol, cigarette smoking, and have increased iron stores, a role for sex hormones, and higher DNA synthetic activities in male patients compared to females [14]. AFP is often elevated in HCC [15]. The relationship between viral etiology and AFP levels in HCC is still unclear [16]. In recent years, use of serum AFP as a diagnosis and/or prognosis biomarker in HCC surveillance has been challenged in developed countries, due to the lack of specificity and sensitivity [17]. In the present study a total of 85(73.27\%) HCC patients showed raised AFP levels, which is in agreement with other studies [18, 19] and slightly lower than Saini N et.al and Manash Sharma et.al. [20,8]. Our study revealed 85.29\%, 73.33\% and 66.66\% AFP positivity among $\mathrm{HBsAg}, \mathrm{HCV}$ and $\mathrm{HBV} / \mathrm{HCV}$ co-infected positive HCC cases respectively. Elevations of alanine aminotrensferase (ALT) and aspartate aminotransferase (AST) may indicate the presence of Hepatocellular predominant disorders [21]. Present study also shows elevated levels of liver enzymes indicating Hepatocellular damage which is in agreement with other studies [11, 22].

\section{Tables}

Table 1. HBsAg and ant-HCV positivity among HCC patients

\begin{tabular}{|l|l|l|l|}
\hline \multicolumn{5}{|c|}{ Total (n=116) } \\
\hline HBsAg positive & $34(29.31 \%)$ & HCV positive & $15(12.93 \%)$ \\
\hline HBsAg negative & $79(68 \%)$ & HCV negative & $98(84 \%)$ \\
\hline Both positive & $03(2.58 \%)$ & & \\
\hline
\end{tabular}

Table 2. Age wise distribution of HBsAg and HCV positive cases among HCC

\begin{tabular}{|c|c|c|c|c|c|c|c|}
\hline & $\begin{array}{l}\text { Total } \\
(\mathrm{n}=116)\end{array}$ & $\begin{array}{l}\text { HBsAg } \\
+ \text { ve }\end{array}$ & $\begin{array}{l}\text { HCV } \\
+\mathrm{ve}\end{array}$ & $\begin{array}{l}\text { Both } \\
+ \text { ve }\end{array}$ & Both -ve & $\begin{array}{l}\text { Either } \\
\text { HBS } \\
\text { Ag/HCV } \\
\text { +ve }\end{array}$ & P Value \\
\hline $\begin{array}{l}21-- \\
30\end{array}$ & $2(1.72 \%)$ & - & - & - & $2(100 \%)$ & $0(0 \%)$ & \multirow{6}{*}{$\begin{array}{l}\text { Chi- } \\
\text { square }= \\
11.869 \\
\text { with } 5 \\
\text { degrees } \\
\text { of } \\
\text { freedom } \\
; \quad P= \\
0.039\end{array}$} \\
\hline $\begin{array}{l}31-- \\
40 \\
\end{array}$ & $\begin{array}{l}12 \\
(10.34 \%)\end{array}$ & $\begin{array}{l}8 \\
(66.66 \%)\end{array}$ & - & - & $\begin{array}{l}4 \\
(33.33 \%)\end{array}$ & $\begin{array}{l}8 \\
(66.67 \%)\end{array}$ & \\
\hline $\begin{array}{l}41-- \\
50\end{array}$ & $\begin{array}{l}17 \\
(14.65 \%)\end{array}$ & $\begin{array}{l}8 \\
(47.05 \%)\end{array}$ & - & $\begin{array}{l}1 \\
(5.88 \%)\end{array}$ & $\begin{array}{l}8 \\
(47.05 \%)\end{array}$ & $\begin{array}{l}9 \\
(52.95 \%)\end{array}$ & \\
\hline $\begin{array}{l}51-- \\
60 \\
\end{array}$ & $\begin{array}{l}44 \\
(37.93 \%)\end{array}$ & $\begin{array}{l}10 \\
(22.72 \%)\end{array}$ & $\begin{array}{l}10 \\
(22.72 \%)\end{array}$ & $\begin{array}{l}1 \\
(2.27 \%)\end{array}$ & $\begin{array}{l}23 \\
(52.27 \%)\end{array}$ & $\begin{array}{l}21(47.73 \\
\%)\end{array}$ & \\
\hline $\begin{array}{l}61- \\
70\end{array}$ & $\begin{array}{l}32 \\
(27.58 \%)\end{array}$ & $8(25 \%)$ & $\begin{array}{l}5 \\
(15.62 \%)\end{array}$ & $\begin{array}{l}1 \\
(3.12 \%)\end{array}$ & $\begin{array}{l}18 \\
(56.25 \%)\end{array}$ & $\begin{array}{l}14(43.75 \\
\%)\end{array}$ & \\
\hline $\begin{array}{l}71- \\
80\end{array}$ & $9(7.75 \%)$ & - & - & - & $9(100 \%)$ & $0(0 \%)$ & \\
\hline
\end{tabular}

Table 3. Sex wise distribution of $\mathrm{HBs}$ Ag positive cases among HCC

\begin{tabular}{|l|l|l|l|}
\hline & HBs Ag Positive $(\mathrm{n}=34)$ & HBs Ag Negative $(\mathrm{n}=79)$ & Both positive $(\mathrm{n}=3)$ \\
\hline Male $(\mathrm{n}=96)$ & $32(33.33 \%)$ & $61(63.54 \%)$ & $3(3.12 \%)$ \\
\hline Female $(\mathrm{n}=20)$ & $2(10 \%)$ & $18(90 \%)$ & - \\
\hline
\end{tabular}

Table 4. Sex wise distribution of HCV positive cases among HCC

\begin{tabular}{|l|l|l|l|}
\hline & HCV Positive $(\mathrm{n}=15)$ & HCV Negative $(\mathrm{n}=98)$ & Both positive $(\mathrm{n}=3)$ \\
\hline Male $(\mathrm{n}=96)$ & $12(12.5 \%)$ & $81(84.37 \%)$ & $3(3.12 \%)$ \\
\hline Female $(\mathrm{n}=20)$ & $3(15 \%)$ & $17(85 \%)$ & - \\
\hline
\end{tabular}

Table 5. AFP levels among HCC patients

\begin{tabular}{|l|l|c|l|}
\hline & Number & AFP High & AFP low \\
\hline HBsAg Pos & 34 & $29(85.29 \%)$ & 5 \\
\hline HCV Pos & 15 & $11(73.33 \%)$ & 4 \\
\hline HBsAg \& HCV Pos & 3 & $2(66.66 \%)$ & 1 \\
\hline Either Positive & 52 & $42(80.76 \%)$ & $10(19.74 \%)$ \\
\hline HBsAg \& HCV Neg & 64 & $43(67.18 \%)$ & $21(33.82 \%)$ \\
\hline
\end{tabular}

\section{Conclusion}

To conclude, our data suggests HBV and HCV play a significant role in the aetiology of hepatocellular carcinoma. Currently available HCC therapies, based on anti cancerous agents, chemotherapy, surgical or radiation-based resection, are inefficient, mainly due to usually late diagnosis and high recurrence rates after surgical resection, and usually end with treatment failure. Thus, prevention of HCC by treating and preventing $\mathrm{HBV}$ and $\mathrm{HCV}$ infection - the major causative agents of $\mathrm{HCC}$ - is of great medical importance. 
Vaccination is the mainstay for HBV prevention, which has proven its effectiveness time and again. Since vaccination programs are causing a reduction in HBV cases, HCV is catching up fast as the leading cause of HCC. As there is no vaccine for $\mathrm{HCV}$, integrated preventive measures such as better blood screening techniques and promoting safe injection practices among IV drug abusers must be the main strategy to reduce $\mathrm{HCV}$ related $\mathrm{HCC}$ risk in the future in most of the world.

\section{Acknowledgements}

We would like to thank Dr. P. Radha Kumari, Professor, Department of Social and Preventive Medicine, Andhra Medical College, Visakhapatnam, for her help in the statistical analysis of the data.

\section{References}

[1]. EASL-EORTC Clinical Practice Guideline Management of hepatocellular carcinoma. J Hepatol. 2012; 56:908-943.

[2]. Subrat K. Acharya. Epidemiology of Hepatocellular Carcinoma in India. Journal of Clinical and Experimental Hepatology | August 2014 | Vol. - | No. - | S27-S33

[3]. NCDC Newsletter. January-March 2014 Volume 3, Issue 1

[4]. R. Kumar. Characteristics of hepatocellular carcinoma in India: a retrospective analysis of 191 cases. Q J Med 2008; 101:479-485

[5]. Birke Bartosch. Hepatitis B and C Viruses and Hepatocellular Carcinoma. Viruses 2010, 2, 1504-1509; doi:10.3390/v2081504

[6]. Geoffrey Zambezi Mutuma1et al. Prevalence of Hepatitis B Virus (HBV) surface antigen and HBV-associated hepatocellular carcinoma in Kenyans of various ages. Afr J Health Sci. 2011; 18:53-61

[7]. Timothy M Block, Anand S Mehta, Claus J Fimmel and Robert Jordan. Molecular viral oncology of hepatocellular carcinoma. Oncogene (2003) 22, 5093-5107

[8]. Manash Pratim Sarma. Viral genotypes and associated risk factors of hepatocellular carcinoma in India. Cancer biol med 2012; 9: 172-181 doi: 10.7497/j.Issn.2095-3941.2012.03.004

[9]. Neeraj Nagaich. Spectrum of hepatocellular carcinoma: study from a tertiary care centre. J cancer prev curr res 2016, 4(6): 00141

[10]. Bansal A, Bansal AK, Bansal V et. al. Association of oncogenic viruses in liver cirrhosis: north India. Int J Health Sci Res. 2014;4(9):224-229.

[11]. Nyasha Chin'ombe. Seroprevalence of HBV and HCV in primary hepatocellular carcinoma patients in Zimbabwe. Infectious Agents and Cancer 2009, 4:15

[12]. Spiros P Hiotis et.al. Hepatitis B vs. hepatitis C infection on viral hepatitis-associated hepatocellular carcinoma. BMC Gastroenterology 2012, 12:64.

[13]. Dina H. Ziada et.al. Prevalence of hepatocellular carcinoma in chronic hepatitis C patients in Mid Delta, Egypt: A single center study. Journal of the Egyptian National Cancer Institute (2016) 28, 257-262.

[14]. Pisit Tangkijvanich, Varocha Mahachai, Pongspeera Suwangool, Yong Poovorawan. Gender difference in clinicopathologic features and survival of patients with hepatocellular carcinoma. World J Gastroenterol 2004;10(11):1547-1550.

[15]. Peng SY, Chen WJ, Lai PL, Jeng YM, Sheu JC, Hsu HC. High alpha-fetoprotein level correlates with high stage, early recurrence and poor prognosis of hepatocellular carcinoma: significance of hepatitis virus infection, age, p53 and $\beta$-catenin mutations. Int $J$ Cancer 2004; $112: 44-50$.

[16]. Kailapuri G. Murugavel et.al. Alpha-fetoprotein as a tumor marker in hepatocellular carcinoma: investigations in south Indian subjects with hepatotropic virus and aflatoxin etiologies. International Journal of Infectious Diseases (2008) 12, e71-e76

[17]. Mingjie Yao, Jingmin Zhao and Fengmin Lu. Alpha-fetoprotein still is a valuable diagnostic and prognosis predicting biomarker in hepatitis B virus infection-related hepatocellular carcinoma. www.impactjournals.com/oncotarget/Vol.7,No.4

[18]. Abbasi A, Bhutto AR, Butt N, Munir SM. Corelation of serum alpha fetoprotein and tumor size in hepatocellular carcinoma. J Pak Med Assoc.2012 Jan; 62(1):33-6.

[19]. Mukherjee S et al. Hepatocellular carcinoma in eastern India, a detail analytical report from a tertiary care hospital. Int J Sci Rep. 2015 May;1(1):69-73

[20]. Saini N, Bhagat A, Sharma S, et al. Evaluation of clinical and biochemical parameters in hepatocellular carcinoma: experience from an Indian center. Clin Chim Acta. 2006; 371: 183-186.

[21]. Hann H-W, Wan S, Myers RE, Hann RS, Xing J, et al. (2012) Comprehensive Analysis of Common Serum Liver Enzymes as Prospective Predictors of Hepatocellular Carcinoma in HBV Patients. PLoS ONE 7(10): e47687. doi:10.1371/journal.pone.0047687

[22]. Dr.K.Narayanasamy, R.Parvathavarthini, Dr.A.Chezhian, Dr.R.Senthil Kumar. A Retrospective Study on Clinical Characteristics of Hepatocellular Carcinoma in a Tertiary Care Hospital. Indian Journal of Applied Research, Vol.IV, Issue.VI June 2014. 